\title{
ANALISIS MANAJEMEN KREDIT UNTUK MEMINIMALISIR KREDIT BERMASALAH (Studi Kasus Pada Lembaga Keuangan Mikro (LKM) di Kota Banda Aceh)
}

\author{
Nyak Umar ${ }^{1}$, Nazariah ${ }^{2}$ \\ ${ }^{1,2}$ Fakultas Ekonomi Universitas Jabal Ghafur Sigli \\ 1nyakumar@unigha.ac.id, ${ }^{2}$ nazariah@unigha.ac.id
}

\begin{abstract}
ABSTRAK
Penelitian ini bertujuan untuk menganalisis penerapan manajemen kredit dalam hal meminimalisir kredit macet, dan upaya penyelesaian kredit macet pada LKM di Kota Banda Aceh.Sampel yang digunakan dalam penelitian ini sebanyak 56 responden. Hasil penelitian menunjukkan bahwa belum maksimalnya penerapan manajemen kredit sehingga masih terjadinya kredit bermasalah namun dari sisi standar rasio yang telah di tetapkan oleh Bank Indonesia bahwa seluruh LKM sudah tercapai standar yang telah ditetapkan, mulai dari rasio Capital Adequacy Ratio, Loan to Deposit Ratio,Non performing loan
\end{abstract}

Kata kunci : Manajemen Kredit, Lembaga Keuangan Mikro, Kredit Macet

\section{Pendahuluan}

Masalah perkreditan yang ditimbulkan dari ketidakpastian pengembalian pinjaman merupakan tugas dan tanggung jawab dari pengelola kredit atau satuan kerja perkreditan.Untuk menangani masalah perkreditan tersebut. Proses Pemberian kredit harus menggunakan prinsip kehatihatian dan monitoring secara ketat tanpa mengabaikan target pemberian kredit yang harus dicapai sesuai dengan kebijakan yang telah ditetapkan. Sikap kehati-hatian merupakan prinsip yang harus selalu diterapkan dalam setiap pemberian kredit, hal tersebut dilakukan agar lembaga Keuangan dapat terhindar atau menekan sekecil mungkin terjadinya risiko kredit bermasalah. Menurut Hariyani (2008), Kredit macet dapat disebabkan oleh faktor internal maupun eksternal. Faktor internal penyebab kredit macet yaitu: kebijakan perkreditan yang ekspansif, penyimpangan dalam pelaksanaan prosedur perkreditan, itikad kurang baik dari pemilik,pengurus atau pegawai, lemahnya sistem informasi kredit macet. Sedangkan faktor eksternal penyebab kredit macet adalah: kegagalan usaha debitor, pemanfaatan iklim persaingan lembaga perkreditan yang tidak sehat oleh debitur, serta menurunnya kegiatan ekonomi dan tingginya suku bunga kredit. Berdasarkan ketentuannya Bank Indonesia (BI) kualitas kredit dapat digolongkan dalam beberapa hal yaitu : Lancar (pas) artinya kredit penyaluran kredit tidak menimbulkan masalah (special mention) artinya kredit sudah mulai memunculkan masalah, sehingga harus mendapatkan perhatian lebih, kurang lancar (substandard) masalah sudah muncul namun nasabah masih membayar kreditnya dalam keadaan tersendat-sendat, diragukan (doubtful) yaitu kemampuan nasabah dalam pembayaran kredit sudah mulai diragukan, dan macet (loss) nasabah tidak mampu lagi dalam membayar kreditnya, sehingga diperlukan penyelamatan (Mulyadi, 2016) Lembaga Keuangan Mikro (LKM) di Kota Banda Aceh sebagai salah satu lembaga jasa keuangan mempunyai kegiatan pokok menerima simpanan dan menyalurkan kredit berupa kredit mikro kepada pengusaha mikro, kecil dan masyarakat Banda Aceh dan sekitarnya. Data di lapangan menunjukkan bahwa masih banyak LKM di Kota Banda Aceh mengalami pengembalian kredit tidak berjalan dengan lancar atau macet sehingga kegiatan operasional lembaga keuangan tersebut macet atau tidak berjalan sebagaimana yang diharapkan. 
Bahwa jumlah kredit macet Pada tahun 2015 mencapai Rp. 10,131,834,865,- dan pada tahun 2016 meningkat menjadi $\mathrm{Rp}$. 11,843,498,676,- sedangkan tahun 2017 jumlah kredit macet meningkat menjadi Rp13,050,885,981,- data ini menunjukkan bahwa jumlah kredit macet selama tahun 2015-2017 meningkat yang seharusnya menurun. Dalam penelitian yang dilakukan oleh Mulyadi (2016) bahwa kredit macet dapat diminimalisir dengan menerapkan manajemen kredit serta analisis kredit dengan menggunakan prinsip 5C yaitu: character, capacity, capital, coleteral dan condition. Sedangkan menurut Hariyani (2008) bahwa analisis kredit bertujuan untuk menentukan kesanggupan dan kesungguhan seorang peminjam untuk mengembalikan pinjamannya sesuai dengan persyaratan yang telah ditentukan.Namun dalam analisis kredit juga digunakan rasio keuangan yaitu capital adequacy ratio, loan to Deposit Ratio, non performing loan.Berdasarkan permasalahan diatas maka peneliti perlu mengkaji lebih mendalam mengenai penerapan manajemen kredit dan analisis yang dilakukan LKM untuk meminimalisir kredit macet.

\section{Telaah Literatur}

\section{Pengertian Manajemen Kredit}

Manajenen kredit merupakan salah satu kegiatan yang paling penting didalam perusahaan manapun dan tidak dapat diabaikan oleh entitas apapun yang terlibat dalam penyediaan jasa kredit dan terlepas dari sifat bisnisnya. Manajemen kredit dari sudut pandang kreditur adalah mengelola keuangan terutama agar utang kreditur tidak mengalami keterlambatan dalam pembayarannya serta tanggung jawab yang harus ditangung oleh debitor dan kreditor.Ketika berfungsi secara efesien, manajemen kredit berfungsi sebagai instrumen yang sangat baik agar bisnis tetap stabil secara financial.

Menurut Hagos Mirach (2010) Manajemen kredit adalah penerapan dan pemeliharaan serangkaian kebijakan prosedur untuk meminimalkan jumlah modal yang terikat pada debitur dan untuk meminimalkan eksposur bisnis terhadap kredit macet. Menurut Rifangga (2015 ) manajemen kredit merupakan sistem pengelolaan kredit yang harus dilaksanakan oleh pihak lembaga keuangan dengan sebaik-baiknya mulai dari perencanaan kredit, penentuan suku bunga kredit, prosedur pemberian kredit, analisis pemberian kredit, sampai kepada pengawasan kredit.

Sejalan dengan pendapat tersebut Mureithi (2014) menyatakan bahwa organisasi yang paling berpengaruh secara historis adalah manajemen kredit, hal ini dikhususkan untuk institusi yang berususan dengan layanan keuangan seperti bank dan lembaga keuangan lainnya. Akan tetapi terlalu mahal bagi lembaga keuangan untuk mengabaikan aspek menajemen kredit mengingat bahwa hasil penjualan secara kredit adalah sumber utama pendapatan lembaga keuangan. Lembaga keuangan yang tidak memperhatikan fungsi manajemen kredit, cepat atau lambat akan mengalami kinerja buruk yang ditandai oleh terjadinya kredit macet.

\section{Proses Manajemen Kredit}

Proses manajemen kredit dimulai dengan menerima permohonan dan selesai ketika peminjam memenuhi semua kewajiban dan mengembalikan semua dana pinjamannya. Manajemen kredit tidak dapat berhasil jika dana pinjaman tidak dapat diterima sepenuhnya. Standar peminjaman yang baik adalah lembaga pemberi pinjaman harus khawatir dengan jaminan pengembalian pinjaman. Manajemen kredit pada dasarnya peduli dengan kewajiban pembiayaan dan mengawasi individu yang berhutang, tujuan utama manajemen kredit dapat dikatakan sebagai mengawasi kredit macet dan meningkatnya aliran dana operasional.Oleh karena itu penempatan sistem yang bertindak sebagai pemeriksaan langsung dari proses pemberian kredit hingga titik pengumpulan harus tepat dan bijaksana (Appiah, Asamoah, dan Narkotey, 2015). Oleh karena itu, manajemen kredit 
harus menetapkan kreteria spesifik yang harus dipenuhi oleh pelanggan sebelum menerima pengaturan kredit yang diusulkan dan sebagai bagian dari proses evaluasi, manajemen kredit juga meminta penentuan total batas kredit yang akan diperluas kepelanggan tertentu (Nsiah Richard, 2014).

\section{Indikator Manajemen Kredit}

Untuk membatasi risiko yang terlibat dalam pemberian fasilitas pinjaman termasuk memeriksa pelanggan untuk menjamin bahwa mereka memiliki kesiapan dan kapasitas.Dalam mengantisipasi risiko kredit, banyak lembaga keuangan menggunakan indikator 5C juga dikenal sebagai standar kredit untuk menilai pelanggan sebagai peminjam potensial.5C bertindak sebagai panduan bagi lembaga keuangan untuk meningkatkan portofolio kredit dan mereka lebih mengenal pelanggannya dengan lebih baik.Adapun 5C adalah sebagai berikut: karakter, kapasitas, jaminan, modal dan kondisi (Mulyadi,2016)

1. Character adalah kesadaran para konsumen dalam sersikap jujur untuk memenuhi kewajiban-kewajibannya. Hal ini sangat penting untuk setiap transaksi kredit yang mengandung kesanggupan untuk membayar kredit.

2. Capacity ' kemampuan pelanggan untuk membayar kembali terhadap pinjaman kredit dan menunjukan perusahaannya beroperasi sukses.

3. Capital Berkaitan dengan modal dan penilaian sumber-sumber keuangan dari pelanggan.

4. Coleteral Ukuran manfaat yang dimiliki pelanggan dapat diakses untuk dimanfaatkan dalam hal jaminan keamanan kredit. Semakin besar ukuran sumber daya pelanggan maka semakin besar peluang perusahaan mendapatkan kepercayaan dalam memperoleh kredit.

5. Condition Iklim ekonomi dan bisnis saat ini serta keadaan unik yangmempengaruhi salah satu pihak dalam transaksi kredit. Analisis kondisis ekonomi dan bisnis, serta keadaan khusus yang dapat mempengaruhi pemohon atau perusahaan dilakukan untuk menilai kondisi. Iklim ekonomi dan bisnis saat ini serta keadaan unik yang mempengaruhi salah satu pihak dalam transaksi kredit.

\section{Analisis Manajemen Kredit}

Salah satu carauntuk mengetahui kesehatan keuangan atau kinerja suatu perusahaan dan masalah-masalah yang sedang dihadapinya dengan rasio keuangan. Analisis rasio keuangan dapat membantu perusahaan dalam mendeteksi masalahmasalah yang dihadapi sehingga dapat melakukan perbaikan-perbaikan untuk mencegah semakin memburuknya kondisi kesehatan perusahaan(Kembau,2014). Adapun alat analisis yang digunakan adalah:

1. Capital adequacy ratio (CAR)

CAR yang juga dikenal sebagai rasio kecukupan modal untuk mengatasi kemungkinan risiko kerugian, mengukur kemampuan suatu perbankan melalui modal dan asetnya. Rumus yang digunakan yaitu:

$C A R=\frac{\text { modal sendiri }}{\text { ATMR }}$

\section{Loan to Deposit Ratio (LDR)}

Loan to deposit ratio adalah rasio antara besarnya seluruh volume kredit yang disalurkan oleh Lembaga keuangan jumlah penerimaan dana dari berbagai sumber. Rumus yang digunakan yaitu:

$$
L D R=\frac{\text { Kredit }}{\text { Dana Pihak Ketiga }}
$$

3. Non performing loan (NPL)

Perbandingan kredit yang tidak dapat dikembalikan oleh debitur alias kredit macet, dengan total kredit yang disalurkan kemasyarakat. Rumus yang di gunakan yaitu:

$$
N P L=\frac{\text { Kredit } \text { Macet }}{\text { Total Kredit }}
$$




\section{Metode Penelitian}

\section{Populasi dan Sampel}

Populasi dalam penelitian ini adalah seluruh manajer LKM di Kota Banda Aceh yang berjumlah 14 responden dan karyawan bagian perkreditan yang berjumlah 42 responden sehingga di totalkan menjadi 56 responden.

\section{Jenis dan Sumber Data}

Penelitian ini merupakan jenis penelitian deskriptif dengan pendekatan kualitatif Pengumpulan data yang digunakan dalam penelitian ini berupa data internal perusahaan berkaitan tata cara penerapan manajemen kredit, penyebab kredit macet dan jumlah kredit macet.

\section{Teknik Pengumpulan Data}

Teknik pengumpulan data dilakukan dengan cara :

1. Wawancara (interview) langsung dengan manajer dan pihak karyawan bagian kredit tentang penerapan manajemen kredit dan tata cara implementasi untuk meminimalisir kredit macet.

2. Dokumentasi adalah pengumpulan data berupa buku-buku yang memuat datadata tentang manajemen kredit dan cara penyelamatan kredit macet.

\section{Alat Analisis Data}

Dalam penelitian ini analisis data dengan menganalisi tata cara pelaksanaan manajem kredit pada lembaga keuangan mikro yang meliputi perencanaan kredit, penentuan suku bunga kredit, mekanisme pemberian kredit, analisis pemberian kredit dan pengawasan kredit.Alat yang digunakan adalah berupa rasio keuangan yaitu Capital adequacy ratio, Loan to Deposit Ratio, Non performing loan.

\section{Hasil Penelitian dan Pembahasan Penerapan Manajemen Kredit}

Manajemen kredit dalam lembaga keuangan mikro (LKM) di Banda Aceh sudah berjalan maksimal baik dari sisi perencanaan maupun implementasi dalam pengelolaan kredit.Penerapan manajemen kredit sudah sesuai dengan prosedur yang akhirnya mencapai pada tujuan dan sasaran. Oleh karena itu penerapan manajemen kredit dimulai dari: 1) perencanaan kredit, 2) penentuan suku bunga, 3) prosedur pemberian kredit, 4) analisis pemberian kredit, 5) pengendalian kredit macet. mekanisme penerapan manajemen kredit sesuai dengan peraturan Bank Indonesia yang telah ditentukan. Sedangkan hasil wawancaran dengan manajer LKM di kota Banda Aceh rata-rata jawaban yang diberikan bahwa penerapan manajemen kredit belum berjalan maksimal, walaupun mekanismennya sudah sesuai.

Hal ini disebabkan masih minimnya pengetahuan pihak LKM dalam menganalisis kredit, kurangnya berpegang teguh pada prinsip kehati-hatian oleh pihak yang memutuskan untuk memberikan kredit dan tidak maksimalnya pengwasan. Sedangkan fungsi manajemen yang dilaksanakan pada LKM di Kota Banda Aceh Sebagai berikut:

\section{Perencanaan Kredit}

Kredit yang akan diberikan penuh dengan ketidak pastian atau disebut juga dengan risiko kredit yaitu kredit macet. Oleh karena itu dalam proses pemberian kredit harus dilakukan perencanaan yang matang atas kredit yang akan diberikan. Perencanaan merupakan sebuah pengkajian yang akan dilaksanakan dimasa yang akan datang. Oleh karena itu, perencanaan kredit yang di lakukan LKM di Kota Banda Aceh untuk melihat berbagai macam aspek baik itu dari faktor resiko maupun dari prospek potensial yang akan diperoleh oleh pihak LKM. Berdasarkan wawancara yang dilakukan dengan pihak manajer LKM “ bahwa perencanaan kredit ada pada bagi manajer perkreditan sehingga tertata dan terlaksana sebagaimana mestinya" adapun perencanaan yang dilakukan pihak manajer LKM di kota Banda Aceh sedikit bervariasi namun tujuan yang dicapai tetap sama yaitu untuk menargetkan penerima kredit yang potensial dan tidak terjadi masalah. Oleh 
karena itu peneliti mendapatkan bahwa perencaan kredit pada LKM sudah baik, namun yang menjadi kendala adalah pada saat implementasi yang kadang-kadang tidak diindahkan oleh pihak karyawan yang melakukan survey dan pihak pengawas yang kurang teliti.

\section{Pelaksanaan Pemberian Kredit}

Pemberian kredit yang di laksanakan oleh LKM-LKM di Banda Aceh adalahdengan prosedur pemberian kredit yang mudah, jaminan kredit, syarat-syarat yang harus dipenuhi cukup efektif untuk menghindari kredit bermasalah. Namun dalam pemberian kredit yang didapatkan dari hasil wawancara peneliti dengan beberapa manajer LKM terdapat beberapa kendala dalam pelaksanaannya terutama dalam analisi kredit yang seharusnya diterapkan prinsip 5C akan tetapi tidak semuanya diterapkan seperti character dan personality sehingga terlaksana dengan kurang efektif. Kurangnya kehati-hatian dalam pemberian kredit terutama yang plafondnya kecil dan masih ditemukan adanya unsur subyektifitas dalam memutuskan kredit.

\section{Pengendalian Kredit}

Kredit merupakan adanya suatu kepercayaan dari pihak pemberi pinjaman kepada penerima pinjaman, bahwa dimasa yang akan datang mampu memenuhi segala kewajiban yang telah diperjanjikan. Namun untuk menjaga kelancaran dalam perkreditan baik dalam melunasi kewajiban maupun dalam kecukupan modal dari pihak LKM maka dibutuhkan pengendalian kredit.Pengendalian kredit merupakan usaha-usaha untuk menjaga kredit yang diberikan tetap lancar, produktif, dan tidak macet. dari hasil penelitian didapatkan berdasarkan wawancara dengan pihak manajemen bahwa pengendalian kredit sudah berjalan lancar, kalaupun adanya kredit macet yang masih terjadi, namun ratarata dari LKM sudah memenuhi unsur pengendalian yang baik mulai dari menganalisa calon nasabah sampai mencari informasi lainya. Ada sedikit permasalahan yang terjadi pada LKM BPTN dimana mereka kurang kehati-hatian dalam memberikan kredit sehinggan menimbulkan kredit yang bermasalah dalam batas ketidak wajaran.

\section{Kebijakan Penyelesaian Kredit Bermasalah}

Setiap pemberian kredit akan terjadi risiko kredit yaitu berupa kredit macet. dengan adanya kredit macet maka mengharuskan pihak manajemen untuk menyelesaikan masalah tersebut supaya tidak terjadi kerugian terhadap LKM. Dari hasil Penelitian didapatkan bahwa rata-rata LKM di Kota Banda Aceh menyelesaikan kredit macet dengan mengedepankan itikat baik dari nasabah.Dari itikat baik tersebut sehingga dapat dinilai sejauh mana komitmen nasabah dalam menyelesaikan kreditnya.Apabila terjadi problem dalam penyelesaianya dengan segera maka pihak LKM memberikan waktu kepada nasabah dalam menyelesaikannya. Berdasarkan penelitian yang dilakukan oleh Mulyadi (2016) Bahwa penyelesaian kredit dengan pendekatan humanis akan dapat menyelesaikan kredit dengan cepat.Namun harus konsiten terhadap sikap dan penyelesaian permasalahan. Oleh karena itu, LKM di kota banda aceh dalam penyelesaian kredit macet dengan pendekatan humanis namun juga terukur terhadap pengambilan tindakan. Selain itu, LKM juga menganalisis faktor-faktor penyebab terjadinya kredit bermasalah, kebanyakan permasalahannya terjadi dari pihak debitur sendiri yaitu kebangkrutan usaha dan permasalahan keluarga.Pihak LKM mengambil kebijakan apabila usahanya terjadi kebangkrutan maka dilakukan analisis penyebab kebangkrtutan. Jika dimungkinkan membantu kembali maka LKM akan membantunya. Berdasarkan wawancara dengan beberapa manajer LKM di Kota Banda Aceh pada bulan juni 2019 bahwa dalam menyelesaikan kredit bermasalah pihak LKM tidak pernah menutup-nutupi adanya 
kredit bermasalah, bahkan pihak manajemen akan membuat tim untuk mendeteksi dan merumuskan penyelesaiannya.

\section{Analisis Rasio Kredit}

Analisis rasio ini adalah untuk mendeteksi secara keuangan terhadap kemampuan lembaga keuangan mikro dalam pemberian kredit, apakah masih dalam katagori sehat atau sebaliknya berdasarkan Peraturan BI No. 13/PBI/201. Adapun analisis yang digunakan yaitu :

\section{Capital Adequacy Ratio (CAR)}

CAR yang juga dikenal sebagai rasio kecukupan modal untuk mengatasi kemungkinan risiko kerugian, mengukur kemampuan suatu perbankan melalui modal dan asetnya.CAR digunakan untuk melindungi para nasabah dan menjaga stabilitas maupun efisiensi sistem keuangan.

Kriteria
Permodalan
\begin{tabular}{|c|c|c|}
\hline $\begin{array}{c}\text { Perin } \\
\text { gkat }\end{array}$ & KPMM & Kriteria KPMM \\
\hline 1 & Sangat sehat & CAR $>12 \%$ \\
\hline 2 & Sehat & $9 \% \leq \mathrm{CAR}<12 \%$ \\
\hline 3 & Cukup sehat & $8 \% \leq \mathrm{CAR}<9 \%$ \\
\hline 4 & Kurang sehat & $6 \% \leq \mathrm{CAR}<8 \%$ \\
\hline 5 & Tidak sehat & CAR $<6 \%$ \\
\hline
\end{tabular}

\section{Capital Adequacy (CAR) LKM di Banda Aceh}



Berdasarkan Tabel diatas bahwa Lembaga keuangan mikro (LKM) di Kota Banda Aceh rata-rata dikategorikan sebagai lembaga Keuangan yang sehat. Sehubungan dengan matriks penilaian komposit, dikategorikan dalam peringkat 2 karena rasio kewajiban penyediaan modal minimum (KPMM) lebih tinggi dan sangat signifikan dibandingkan dengan rasio KPMM yang ditetapkan dalam ketentuan, karena persentase pertumbuhan modal lebih tinggi dibandingkan dengan persentase pertumbuhan ATMR. Oleh sebab itu, kriteria penilaian kesehatan LKM rata-rata CAR > 11\% maka rasio permodalan LKM di Kota Banda Aceh dalam predikat sehat.

Pihak lembaga LKM harus mempertahankan CAR diatas $8 \%$ yang telah ditetapkan oleh pihak Bank Indonesia, karena apabila CAR yang semakin rendah akan menyebabkan turunnya kepercayaan masyarakat. hal ini disebabkan karena salah satu fungsi modal untuk menjaga kepercayaan masyarakat. Sebaliknya semakin tinggi CAR yang dicapai oleh suatu Lembaga Keuangan menunjukkan kinerja Lembaga Tersebut semakin baik karena bank tersebut mampu untuk menutupi penurunan aktivanya sebagai akibat dari kerugian-kerugian yang disebabkan oleh aktiva yang berisiko dengan kecukupan modal yang dimilikinya. Dengan kata lain, semakin kecil risiko suatu LKM maka semakin meningkat keuntungan yang diperoleh.

\section{Loan to Deposit Ratio (LDR)}

Loan to deposit ra adalah rasio antara besarnya seluruh volume kredit yang disalurkan oleh bank jumlah penerimaan dana dari berbagai sumber

Kriteria tingkat LDR

\begin{tabular}{|c|c|c|}
\hline Peringkat & KPMIM & Kriteria KPMIM \\
\hline 1 & Sampat sehat & LDR $>75 \%$ \\
\hline 2 & Sehat & $75 \% \leq$ CAR $<85 \%$ \\
\hline 3 & Cukup sehat & $85 \% \leq$ CAR $<100 \%$ \\
\hline 4 & Kurang sechat & $100 \% \leq$ CAR $<120 \%$ \\
\hline 5 & Tidak sehat & CAR $<120 \%$ \\
\hline
\end{tabular}




\section{Loan to Deposit Ratio (LDR) Lembaga Keuangan Mikro di Banda Aceh}

\begin{tabular}{|c|c|c|c|c|c|c|}
\hline \multirow[b]{2}{*}{$\mathrm{S}_{\mathrm{s}}$} & \multirow[b]{2}{*}{ Narna LKM } & \multicolumn{4}{|c|}{ LDR yaug dicapai } & \multirow[t]{2}{*}{ Keternaget } \\
\hline & & 2016 & 2017 & 2018 & 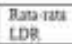 & \\
\hline 1 & LKM BQ Baitumalmin & 72.02 & 90.13 & $\$ 9.28$ & 77.14 & Sehat \\
\hline 2 & LKM Koperete & 77,3 & 73.74 & 8235 & 77.79 & Sehat \\
\hline 3 & LKM BQ Cut Nyak Diti & 43.92 & 53.8 & 66.41 & 54,71 & Sangat Solhin \\
\hline 4 & LKM Kisaht 24 & 72.49 & 46.49 & 52.75 & 57,24 & Saugat Schant \\
\hline 5 & LKM BPRS Hikmab Wakilah & 28.41 & 28.3 & 59.1 & 38.60 & Sangat Sehate \\
\hline 6 & LKM BPR Beflis & 72.12 & 85.35 & 85.35 & 80.94 & Selast \\
\hline 7 & LKM BPRS Banturnthimain & 50.62 & 58.6 & 41.78 & 59,33 & Sangat sedint \\
\hline 8 & LKM BPR Anthes & 50.15 & 72.49 & 54.11 & 58.9 & Sanzat Selone \\
\hline 9 & LKM BPR Harkait Lambaro & 35,03 & 43.62 & 553 & 44.65 & Sampat sehat \\
\hline 10 & LKM BQ Bsilumaluna & 43.9 & 92.32 & 55.4 & 30.54 & Salugat sehat \\
\hline II & LKMMLM Syariá & 76.97 & 55.8 & 50.23 & 61 & Sangat Sehant \\
\hline 12 & LKMBTPN & 91.82 & 93,49 & 9225 & 92.52 & Sehat \\
\hline B] & LKM Ulam PNM & 40.43 & 52.39 & 57.03 & 49,95 & Sangit sechat \\
\hline 14 & LKM Mandiri Darnosolum & 72.11 & 75.17 & 89.93 & 79.07 & Sehat \\
\hline
\end{tabular}

Hasil penelitian menunjukkan bahwa LKM di Kota Banda Aceh telah berhasil melakukan penyaluran kredit (yang ditandai dengan angka LDR) yakni telah mencapai batas yang telah di tentukan oleh Bank Indonesi $75 \%<$ rasio $<120 \%$ atau rasio < $50 \%$ kondisi ini bisa kita lihat pada 14 LKM tersebut dimana LKM-LKM tersebut menyalurkan kreditnya sangat tinggi.hal ini diharapkan kepada LKM supaya dalam penyalurannya perlu kehati-hatian karena akan menciptakan terjadinya kredit macet.

Dari tabel diatas bisa kita lihat bahwa LKM di kota Banda Aceh sudah berani menyalurkan kredit tanpa di banyangi rasa ketakutan lagi. Jika rasio LDR tumbuh terlalu besar menggambarkan bahwa LKM terlalu besar menyalurkan kredit dibandingkan sumber dana yang tersedia. Dikarenakan dana yang diperoleh seluruhnya dioperasionalkan kedalam kredit. Jika kualitas kredit tumbuh dengan rendah maka mampu meningkatkan LDR yang tetap berada pada batas ketentuan BI.Namun dari hasil wawancara dengan beberapa pimpinan LKM bahwa penyaluran kredit yang mereka lakukan lebih kepada usaha kecil dan menengah, tingginya LDR kemungkinan pihak LKM sudah mempermudah syaratsyarat yang telah ditentukan. Selain itu pihak LKM dalam 3 tahun terakhir mereka membuat sistem jemput bola artinya bahwa dalam penyaluran kredit mereka akan terjun kelapangan untuk menawarkan kredit tersebut secara langsung.

\section{Non performing loan (NPL)}

Non performing loan (NPL) adalah salah satu indikator kunci untuk menilai kinerja fungsi lembag keuangan , karena NPL yang tinggi adalah indikator gagalnya suatu lembaga keuangan dalam mengelola bisnis antara lain timbul masalah likuiditas (ketidakmampuan membayar pihak ketiga), rentabilitas (hutang tidak dapat ditagih), dan solvabilitas (modal berkurang). Laba yang merosot adalah salah satu imbasnya karena praktis lembaga keuangan kehilangan sumber pendapatan disamping harus menyisihkan pencadangan sesuai kolektibilitas kredit.NPL mencerminkan juga risiko kredit, semakin tinggi tingkat NPL maka semakin besar pula risiko kredit yang ditanggung oleh pihak keuangan. Berdasarkan Ketentuan Risiko likuiditas dengan menggunakan rasio non performing loan sesuai dengan (Peraturan BI No. 13/PBI/2011) tingkat kesehatan Lembaga Keuangan berdasarakan kriteria sebagai berikut:

Kriterian NPL Yang ditentukan Oleh Bank Indonesia

\begin{tabular}{|c|c|c|}
\hline Peringkat & KPMM & Kriteria KPMM \\
\hline 1 & Sangat sehat & NPL $\leq 2 \%$ \\
\hline 2 & Sehat & $2 \% \leq \mathrm{NPL}<5 \%$ \\
\hline 3 & Cukup sehat & $5 \% \leq \mathrm{NPL}<8 \%$ \\
\hline 4 & Kurang sehat & $8 \% \leq \mathrm{NPL}<12 \%$ \\
\hline 5 & Tidak sehat & $\mathrm{NPL}<12 \%$ \\
\hline
\end{tabular}

Non Performing Loan (NPL) Lembaga Keuangan Mikro di Banda Aceh

\begin{tabular}{|c|c|c|c|c|c|c|}
\hline \multirow[b]{2}{*}{ No } & \multirow[b]{2}{*}{ Nama LKM } & \multicolumn{4}{|c|}{ NPL yang dicapai } & \multirow[b]{2}{*}{ Keterangan } \\
\hline & & 2016 & 2017 & 2018 & $\begin{array}{l}\text { Rositerntats } \\
\text { NPL }\end{array}$ & \\
\hline 1 & LKM BQ Baiturraluman & 3.65 & 2.39 & 2.41 & 2.81 & Sebat \\
\hline 2 & LKM Kopessem & 4.86 & 39 & 5.8 & 4.85 & Schat \\
\hline 3 & LKM BQ Cut Nyak Din & 3.86 & 2.29 & 4.89 & 3.68 & Schat \\
\hline 4 & LKM Kisah 24 & 6.56 & 4.04 & 5.43 & 4.73 & Selant \\
\hline 5 & LKM BPRS Hikmah Wakilat & 3.54 & 3,37 & 3.47 & 3.46 & Sehat \\
\hline 6 & LKM BPR Berlias & 2.18 & 5,43 & 4.36 & 3.99 & Sehat \\
\hline 7 & LKM BPRS Baiturabtuan & 4.79 & 2.66 & 3.72 & 3.72 & Sehat \\
\hline 8 & LKM BPR Artha & 6.2 & 5,43 & 5.23 & 5.62 & Selat \\
\hline 9 & LKM BPR Harkat Lambaro & 4.3 & 3.4 & 2.83 & 3.51 & Sehat \\
\hline 10 & LKM BQ Baiturrahman & 1.98 & 2.01 & 1.06 & 1.68 & Sangat Sehar \\
\hline 11 & LKM MUM Syariah & 3.9 & 3.7 & 2.6 & 3.4 & Sehat \\
\hline 12 & LKM BTPN & 9.61 & 7.71 & 9.34 & 8.88 & Kurang Sehut \\
\hline 13 & LKM Ulanu PNM & 1.05 & 2.02 & 1.89 & 1.65 & Sangat selat \\
\hline 14 & L.KM Mandiri Danussalam & 3.15 & 2.99 & 2.8 & 2.98 & Sehat \\
\hline
\end{tabular}

Rasio Non Performing Loan yang terjadi pada LKM di Kota Banda Aceh ditahun 2016-2018 secara rata-rata berada pada peringkat 2 dengan tingkat kesehatannya adalah "Sehat" itu artinya LKM tersebut Mencerminkan kondisinya 
yang secara umum sehat sehingga dinilai mampu menghadapi pengaruh negatif dari perubahan kondisi bisnis dan faktor eksternal lainnya tercermin dari risiko kredit yang secara umum sangat baik. Apabila terdapat kelemahan maka secara umum kelemahan tersebut kurang baik. Dari penjelasan semua LKM tersebut maka LKM ini telah berhasil meningkatkan dananya untuk disalurkan kedalam kredit, semakin besar jumlah kredit ini disalurkan maka akan semakin besar pula tingkat kemungkinan tidak diterimanya kembali dana yang telah disalurkan tersebut akibat kegagalan dalam pembayaran oleh nasabah artinya semakin besar risiko kredit bermasalah yang menjadi macet. Kredit bermasalah yang terjadi bukan saja akan kehilangan pendapatan atas bunga kredit melainkan juga LKM akan kesulitan untuk memenuhi likuiditasnya. Tetapi meskipun terjadinya peningkatan kredit bermasalah namun tidak mempengaruhi atas jumlah kredit yang diberikan, jumlah kredit yang diberikan bahkan mengalami peningkatan dari tahun ke tahun, dan NPL yang tumbuh juga tidak melebihi batas ketentuan dari Bank Indonesia.Namun dari data diatas ada LKM yang kurang sehat yaitu LKM BTPN.Dari hasil wawancara dengan manajemen LKM BTPN bahwa banyaknya kredit macet terjadi disebabkan pada tiga tahun terakhi pemberian kredit tidak sesuai prosedur yang telah ditentukan sehingga mengalami kredit macet.Seperti jumlah kredit yang diberikan harus sesuai dengan anggunan.

\section{Kesimpulan}

Penerapan manajemen kredit di lembaga keuangan mikro sudah sesuai aturan yg di keluarkan oleh bank Indonesia, namun dalam mengimplementasikannya belum maksimal. Akan tetapi rata-rata lembaga keuangan mikro sudah menjalankan semua unsur yang telah ditentukan oleh BI. Hal ini dapat dilihat dari nilai yang dihasilkan oleh Capital Adequacy Ratio, dimana nilai yang dihasilkan oleh CAR dalam keadaan normal atau sehat, begitu juga dengan nilai yang dihasilkan oleh Loan to Deposit ratio dimana nilai yang dihasilkan oleh LKM di Kota Banda Aceh dalam keadaan sehat. Begitu juga dengan nilai Non Performing Loan, dimana nilai yang diperoleh oleh LKM rata-rata sehat. Dari sisi pengawasan, LKM sudah menjalankannya secara maksimal walaupun dalam pelaksanaan masih terdapat kekurangan yang harus diperbaiki.

\section{Saran}

Berdasarkan hasil penelitian dan uraian diatas maka peneliti dapat memberikan beberapa saran. Adapun saransaran yang dapat peneliti sampaikan adalah: Prosedur analisis kredit hendaknya dilaksanakan dengan lebih maksimal dan unsur prinsip 5C dapat dilaksanakan dengan sebaik mungkin, terutama prinsip character dan personality. Bagi pihak pemutus kredit hendaknya lebih berhati-hati sebelum memutuskan kredit dengan meneliti ulang hasil analisis kredit terutama untuk kredit dengan plafond kecil atau kurang dari 5 juta dan meneliti adakah hubungan antara nasabah dan calon debitur agar unsur subyektifitas dapat terhindarkan. Pengawasan kepada nasabah hendaknya dilakukan sebelum terjadi kredit bermasalah secara rutin pada setiap pelaksanaan pemberian kredit.Selain pengawasan kepada nasabah sebaiknya juga perlu untuk lebih ditingkatkan pengawasan terhadap karyawan yang terlibat dalam melaksanakan tugas pemberian kredit, instrumen pendukung dan pengelolaan kredit supaya tidak terjadi penyimpangan atas kredit yang disalurkan.

\section{Daftar Pustaka}

Appiah, K.O., Asamoah, L.A. and Narkotey, Z. (2015) 'Determinants of performance of rural banks in Ghana', African J. Accounting, Auditing and Finance, Vol. 4, No. 4, pp.345-359.

Hagos Mirach (2010) Credit Management(A Case Study Of Wegagen Bank Share Company In Tigray Region) Reg. No-CBE/PRO-021/01 
Hariyani, Iswi. (2008). Hapus Buku \& Hapus Tagih.Surabaya: PT. Bina Ilmu Offset. 2.

Mulyadi, Dedi (2016) Analisis Manajemen Kredit Dalam Upaya Meminimalkan Kredit Bermasalah (Studi Pada Pt. Bpr Pantura Abadi Karawang) Jurnal Manajemen \& Bisnis Kreatif Issn 2528-0597 Vol, 1 No, 2, 2016

Nsiah Richard (2014) An Examination Of The Credit Management Practices Of Rural Banks: A Case Study Of
Asokore Rural Bank Limited SSRN Electronic Journal DOI: $10.2139 /$ ssrn. 2494259

Kembau, Rendikasa P. H. (2014) pengaruh rasio hutang dan rasio kredit terhadap profitabilitas dan dampaknya terhadap rasio lancar pada perusahaan leasing yang terdaftar di idx. Jurnal EMBA. Vol.2 No.4 Desember 2014, Hal. 374385 